University of Wollongong

Research Online

Faculty of Social Sciences - Papers (Archive) Faculty of Arts, Social Sciences \& Humanities

2015

Banking Spatially on the Future: Capital Switching, Infrastructure, and the Ecological Fix

Noel Castree

University of Wollongong, ncastree@uow.edu.au

Brett Christophers

Uppsala University

Follow this and additional works at: https://ro.uow.edu.au/sspapers

Part of the Education Commons, and the Social and Behavioral Sciences Commons

Research Online is the open access institutional repository for the University of Wollongong. For further information contact the UOW Library: research-pubs@uow.edu.au 


\title{
Banking Spatially on the Future: Capital Switching, Infrastructure, and the Ecological Fix
}

\begin{abstract}
Since the onset of the global economic crisis, financiers and the institutions regulating their behavior have been subject to far-reaching criticism. At the same time, leading geo-scientists have been insisting that future environmental change might be far more profound than previously anticipated. Finance capital has long been a crucial mechanism for melting present solidities into air to create different futures. This article asks what the prospects are for the switching of credit money into green infrastructures-a switching increasingly recognized as necessary for climate change mitigation and (especially) adaptation. Most research into geographies of finance has ignored ecological questions and few contemporary society-nature researchers examine major fixed-capital investments. Unlike those geographers who criticize capitalism without offering feasible alternatives, we take a pragmatic view underpinned by democratic socioenvironmental values and attempt to identify leverage points for meaningful change. This programmatic article identifies reasons and examples to be cautiously hopeful that liquidity can be fixed in less ecologically harmful future infrastructures, thereby addressing crucial extraeconomic challenges for the century ahead.
\end{abstract}

\section{Keywords}

future, capital, banking, switching, spatially, infrastructure, ecological, fix

\section{Disciplines}

Education | Social and Behavioral Sciences

\section{Publication Details}

Castree, N. \& Christophers, B. (2015). Banking Spatially on the Future: Capital Switching, Infrastructure, and the Ecological Fix. Annals of the Association of American Geographers, 105 (2), 378-386. 


\title{
Banking spatially on the future: capital switching, infrastructure and the ecological fix
}

\begin{abstract}
Since the onset of the global economic crisis, financiers and the institutions regulating their behavior have been subject to far-reaching criticism. At the same time, leading geo-scientists have been insisting that future environmental change may be far more profound than previously anticipated. Finance capital has long been a crucial mechanism for melting present solidities into air so as to create different futures. This article asks what the prospects are for the switching of credit money into green infrastructures - a switching increasingly recognized as necessary for climate change mitigation and (especially) adaptation. Most research into geographies of finance has ignored ecological questions while few contemporary society-nature researchers examine major fixed-capital investments. Unlike those geographers who criticize capitalism without offering feasible alternatives, we take a pragmatic view underpinned by democratic socioenvironmental values and attempt to identify leverage points for meaningful change. This programmatic article identifies reasons and examples to be cautiously hopeful that liquidity can be fixed in less ecologically-harmful future infrastructures, thereby addressing crucial extraeconomic challenges for the century ahead.
\end{abstract}

Keywords Finance capital; infrastructure; capital switching; climate change; regulation

\section{Introduction}

Given the inherent unknowability of the future, foreseeing its socio-ecological parameters and possibilities is a challenging task at the best of times. However, notwithstanding all the future uncertainties with we which we must deal, two things are increasingly clear. The first is that anthropogenic climate change is occurring and to a degree likely to prove "game changing" for most countries worldwide. The second is that such change will necessitate significant, pro-active socio-economic reconfigurations that both respect, and yet also help to write, the new rules of the ecological game. One such vector of reconfiguration, and the one considered in this article, pertains to the built environment - that is, to those long-lasting, expensiveto-construct physical infrastructures that both enable and constrain the quotidian activities involved in reproducing social life.

In what specific senses does anthropogenic climate change call for such reconfiguration? For several years analysts and policymakers have talked incessantly about "mitigation" and "adaptation" strategies. In respect of infrastructural changes, Pacala and Socolow (2004) have argued influentially that a rapid reconfiguration of the existing built environment - prioritizing "efficient buildings" - can contribute substantially to limiting future atmospheric warming. However, given the relative failure of most national governments to pursue mitigation strategies aggressively, adaptation is now at least as vital thinking ahead. The recent (fifth) assessment report of the Intergovernmental Panel on Climate Change (2013) indicates with high certainty that an average atmospheric temperate rise of as much as 4 degrees Celsius 
by century's end is possible. In this light, it is hard to disagree with Nathan Sayre's contention that "A rapid and comprehensive reconfiguration of the built environment is imperative if we are to ... adapt to global warming" $(2010,95)$. Sayre then goes on to identify what we agree is a pivotal question: that of how, and by whom, a comprehensive remaking of built environments might be financed.

Drawing on David Harvey's (1982) seminal work on the distinctive political economy of major fixed-capital investment, Sayre reminds us that the built environment "depends heavily on financial instruments and institutions that permit large-scale borrowing and long-term amortization" (2010, 102). Recognizing such economic distinctiveness, our article's contribution to the imagination of socioecological futures is to explore how, in principle, the financing of major new infrastructure might work, and to consider how likely such financing is to eventuate soon. Notwithstanding the tarnished image financiers have because of the global financial crisis and its fall-out (plus various high-profile scandals), their decisions will be crucial in determining the road humanity will travel in the decades to come. There is a need for analysts and policymakers not only to understand these decisions but to shape them in order to realize important non-economic goals. In effect, the financial sector is an unelected government whose power is such that it needs to be carefully governed through a set of endogenous and exogenous norms, rules and institutions. In respect of infrastructure, one might say that (some) financiers are the ultimate geographers, literally graphing the face of the earth as they translate liquidity into enduring fixed assets essential to our shared future. To use another metaphor, in designing the arteries through which future capital will flow, these financiers stand to determine the future health not only of 'the economy', but of the bodies social and ecological too.

Normatively, and contrary to much geographical research into humanenvironment relationships, our explicit aim is to offer an even-handed appraisal of the possibilities capitalism offers for enabling humanity - or significant parts of humanity - to cope with what is likely to be an ecologically challenging future. Consider here differing uses of the word "fix", which completes our article's title. For many critical geographers (and we consider ourselves such), the word usually has negative, even pejorative, connotations over-and-above its explanatory meanings. In the context of our current political economy, a fix is typically seen as capitalism trying to negotiate its inherent crisis tendencies so as to reproduce itself in perennially iniquitous forms. Thus, for Erik Swyngedouw (2010, 222), capitalist enthusiasm for 'eco-technologies' like smart energy meters is essentially about "producing a socioecological fix to make sure nothing really changes. Stabilizing the climate seems to be a condition for capitalist life as we know it to continue." We do not diminish such concerns. But here we use the word 'fix' differently to denote the possibility of an ecologically- and socially-progressive reconfiguration of existing built environments. Such a fix can never be problem-free, and what counts as "progressive" is relative to 
be sure. Moreover, naïve optimism should never substitute for reasoned and realistic hope that certain specific varieties of capitalism can deliver wider socio-ecological benefits for more than just a few. But equally, as J-K Gibson-Graham has argued consistently (e.g. 2008), such hope is absent when critics see capitalism as little more than a malign and impregnable force that disadvantages the majority of humanity. In sum, this is a programmatic article intended to highlight real-world issues pertaining to future infrastructure financing and to inspire thought among geographers about how they choose to examine these issues looking ahead.

\section{Anthropogenic climate change and capital switching}

In 2012 the British government, in the shape of the Department for Environment, Food \& Rural Affairs, published the first of its new five-yearly Climate Change Risk Assessment reports (Defra, 2012). Among other things, the document was notable for highlighting perceived "priorities for adaptation" under five headings, one of which was 'Buildings \& Infrastructure.' This identification of the need for built-environment renewal reflects increasingly widespread consensus, not only in the U.K. but internationally, regarding the centrality of infrastructure upgrade to what Defra calls "climate resilience" (flooding and overheating of buildings being seen as the most significant risks in the British case). But there is also, as already intimated, a perceived role in climate change mitigation. Defra's conviction that building a "new low carbon infrastructure" can assist in "the transition to a low carbon economy" is underpinned by the fact that, in Sayre's $(2010,95)$ words, the existing built environment "mediates economic production, exchange and consumption in ways that both presuppose and reinforce high rates of greenhouse gas emissions."

Given the growing acceptance that our infrastructures need to be substantially redesigned and renewed, planners and other experts are turning their attention to the critical question of what more resilient and energy-efficient ones might look like. This is not the place to consider this question in any detail. Suffice to say that the proposals which are now beginning to emerge share two main attributes. First, there is a strong emphasis on coastal regions, where the impact of rising sea levels will be most pronounced. Second, there is an emphasis on cities, reflecting the fact that the world's built environment is primarily urban. Brian Stone's (2012) The City and the Coming Climate is a good example: it makes concrete proposals for new energy, residential and transport infrastructures under the 'coming' climate and associated physical geography.

Alongside such envisionings of future built environments, we are also seeing tentative appraisals of the potential costs thereof. Such costs, needless to say, will be colossal, and their quantification at this juncture is challenging. For example, a recent report (Hallegatte et al., 2013), assuming a mean sea-level rise of 0.2-0.4 meters by 2050, and seeking to quantify the impact of flooding on the world's 136 largest coastal cities, estimated necessary infrastructure adaptation costs at a cumulative 
US $\$ 50$ billion per annum. The authors stress, however, that while such figures may sound high, they are "far below [their] estimate of aggregate damage losses per year in the absence of adaptation" (ibid., 805). This qualifier echoes the now famous conclusion of the Stern Review (2007) that the relative economic costs of inaction vastly outweigh those of acting meaningfully now.

All of this tells us that the redesigning and rebuilding of infrastructures will require a long-lasting diversion of financial investment from existing uses. Global society, in other words, will have to effect a massive "capital switch". Harvey (1978) conceptualized this as the process whereby investment is re-routed from one "circuit of capital" to another. He was most interested in the case where the switch is from the "primary"circuit of "productive" capital (investment in the wage-labor-based production of goods and services for sale on the market) to the "secondary" circuit of investment in the (re)construction of built environments (e.g. roads and factories). This begins to explain the appeal of the 'capital switch' optic for us here. It refers to large-scale, temporally-concentrated diversions of investment that serve to alter systematically the historically-contingent forms that capitalism assumes. It is just such diversions that are pivotal to global attempts to cope with future climate change.

Such switches have certainly happened before - indeed Harvey regards them as part of capitalism's metaphorical DNA. As such, the general dynamics of the "ecological" switch envisioned in this article would not be unprecedented, even if its magnitude might be. Such a switch would involve protecting existing "natural capital" (e.g. large areas of forest, today reframed as providers of "ecosystem services'), creating "green infrastructure" en masse, and fabricating built environments designed to cope with higher sea levels, warmer temperatures and so on. Yet, as theorized by Harvey and examined by scholars mobilizing his theoretical lens, capital switching is ultimately a function of short-term capitalist profit-seeking. It is, at heart, a response to an immediate crisis of economic capital (specifically, a crisis of over-accumulation, and thus of surplus capital in search of a "home"). At best, it also provides a temporary "fix" to the crisis tendencies necessitating it. This being so, how can we foresee a switch necessitated in large part for ecological reasons and with the long-term viability of biophysical goods and services as a key motivation? If not from an acute dearth of current opportunities for profitable investment in the "productive" circuit, and thus for ongoing economic growth, where will the impetus to switching come from (and over what timescale)? Additionally, how enduring will the infrastructural products of such a switch, should it and they eventuate, prove to be?

We do not pretend to know the answers. But on several accounts the theory and historical reality of capital switching suggest that the 'fix' envisioned here is not unimaginable. First, if Harvey is right, capital switching occurs necessarily - it happens regardless of the "extra-economic" reasons that may be used to encourage, or justify, such a switch. Second, when "extra-economic" factors come to have serious economic consequences they become internalized within the "logic" of capitalism. To 
quote Sayre once more on infrastructure, “...by a fortuitous paradox, these [fixed capital] investments are threatened with devaluation whether or not we act to stabilize atmospheric GHG concentrations; in highly uneven, unpredictable, and potentially abrupt ways, global warming will make our current built environment increasingly untenable and uneconomical" $(2010,95)$. This is a reminder that capital functions in a world that never was, nor will ever be, designed to meet the changing "needs" of this mode of production. Third, financial institutions have long been accustomed to translating short-term money-making opportunities into the sort of long-term commitments needed to build and maintain something like a nuclear power facility. Given the right incentives by governments, financiers are well capable of crafting investment vehicles to help decarbonize the world's current infrastructural assets.

Fourth, and relatedly, though global capitalism remains broadly neoliberal, national governments retain the power to radically alter the regulatory conditions that define "rational" and permissible financial activities. They also, of course, can be direct participants in a capital switch by choosing to make large public investments. Even 'night watchman' states have some more than nominal sense of the public interest, not least because civil society actors force them to look beyond the immediate needs of business. In the present case, an increasingly large and vocal community of geoscientists is urging governments to take global environmental change far more seriously than heretofore. Alarmed by the so-far weak attempts to decarbonize the world economy, these geoscientists are sounding a drum-beat of alarm intended to be heard by leading politicians (see, for instance, The Stockholm Memorandum, 2011). Their concerns are echoed by leading NGOs, foundations and charities, and are part of a wider questioning of contemporary capitalism that precedes the recent financial meltdown. The fact that none of this is at all new indeed, it is all-too-familiar - helps to create the material preconditions for the sort of policy shift that will be one "form of appearance" of the causal necessity Harvey's switching idea identifies. In short, if capital switching can never be a purely economic affair, there are general reasons to believe causal necessity and contingent causality might fortuitously combine to reconfigure capitalism's operating "hardware" along more "ecofriendly" lines. These reasons may not be sufficient to win any argument on the subject, but neither should they be dismissed.

Of course, should such a reconfiguration occur two important distributional questions arise. First, because the scope and scale of contemporary capitalism is unprecedented, the infrastructural transformation being envisaged here could not simply be regional in scale. It would have to be global, raising the question: how feasible is this? Second, as several commentators have shown (e.g. Graham and Marvin, 2001), many contemporary infrastructures offer declining "public goods" functions as they are increasingly targeted to privileged social groups. In this regard it is clearly not hard to imagine a bleak future in which new ecologically-resilient 
infrastructures serve - and generate economic growth for - only those few who can pay for them. This therefore begs a second question: can a different future eventuate?

Again, there are general reasons to believe that both questions can be answered in the affirmative. First, unless capitalism were to deglobalise through force of circumstance, its future trajectory virtually requires the coincident alteration of infrastructures across continental boundaries. The time-space compression that is one of capitalism's hallmarks typically forges built environments conducive to commodity circulation on the largest possible scale at any one historical moment. Barriers to circulation are typically overcome because they are both opportunities for and drags on productive investment. Second, though in many places future infrastructures will likely not bring benefits to a great many citizens (see the next section for more on this), in many other cases a grass-roots Polanyian countermovement against such exclusion is conceivable. In still other cases non-neoliberal governments may have strong public-interest agendas; and we should remember, too, that capital ultimately suffers (indeed, faces the crises that trigger switches) if too few people consume the things it commodifies.

Let us now move away from these general considerations toward a more focused examination of how ripe finance capital is to effect the switch we have been discussing. The central investment issues, as we see them, are threefold and intimately connected. The remainder of the article proceeds with this generic outlining of future financing possibilities as background:

1. Source of funds. Here the question is a nominally simple one: who would pay? While funding could of course come from many different sources, the key generic distinction is between private and public finance. Would the rebuilding of our built environments be financed by private, commercial interests, or by the state (and thus, ultimately, various taxpayers)? While some of the new infrastructure would be privately-owned and revenue-generative, much of it transportation infrastructures (without tolls or other user fees), coastal defenses, and so forth - could not and would not be. In the latter case, it is more difficult - though clearly not impossible - to envision a significant role for private capital.

2. Nature of funds. Would the capital being invested be cash or credit? That is to say: would it be derived from actually-existing financial assets without matching liabilities, or would the funding entity be required to borrow in order to make the investment? An example of the former would be a pension fund or sovereign wealth fund (SWF). An example of the latter, at least in most Western countries, would be the state - as we are only too well aware, few Western governments today have the luxury of spending without borrowing first. Borrowing is likely to be essential to one degree or another.

3. Form of investment of funds. Where the infrastructure investor and owner are not one and the same, would capital be invested as debt or as equity? Or, to 
put it another way, to what types of returns would the investor be entitled interest and principal repayments (debt) or payments tied to the market value of the investment (equity)? The latter is only conceivable in instances where ownership of the infrastructure is wholly or partly private, and thus would be likely to be relatively limited. This has significant implications, with debt and equity investments typically characterized by different risk profiles and attractive to investors with different risk appetites.

\section{Barriers to realization}

For all our desire to present a balanced outlook on the need and possibility of effecting an ecological fix underpinned by new societal infrastructures, we are mindful of the necessity to acknowledge the many reasons to be skeptical. In this section we enumerate some of the more important of these. To be clear, our concern here is not with technical barriers but with the obstacles that existing configurations of finance capital pose, and with ominous ongoing dynamics in and around current (financial) political economy. We identify five related sets of challenges in this sphere:

1. Given that much of the new infrastructure will not be designed to be revenuegenerative, and will be publicly owned and controlled, it is difficult to imagine that it can be financed without a significant contribution from public sources. Yet we stand at a moment in history where, certainly in the Global North, public finances are under - or at least, are seen and asserted to be under - exceptional pressure. The timing, in other words, is anything but propitious: in a milieu where the political and public appetite for taking-on more long-term public debt is virtually non-existent, and, moreover, where the appetite for higher taxes (the other, "unmentionable" mechanism for raising funds) is equally limited, it is hard to see public financing as solving the problem in toto or even in large part. Witness, for instance, the situation in the U.S., where plans for a national infrastructure bank using federal funds remain stalled despite backing from President Obama and numerous influential senators.

2. There is also something of a philosophical - as opposed to a political-economic - barrier to the notion of public financing of major infrastructure renewal. As O'Neill (2013) has shown, a major trend of the late $20^{\text {th }}$ and early $21^{\text {st }}$ centuries has been towards privatization of the ownership, financing and operation of infrastructure. In the resulting ideological-discursive environment, where "state responsibility for infrastructure and public acceptance for its finance and delivery" are "no longer intrinsic to Western capitalist ideology" (ibid. 3) in the way they once were, the challenges confronting future public financing of builtenvironment reconstruction loom larger still.

3. If the necessary means to finance reconstruction publicly are neither readily available nor perhaps readily justifiable, a different set of obstacles threatens the viability of private financing. Perhaps the biggest concerns the question of 
whether investment in such reconstruction would be deemed sufficiently attractive (i.e. profitable). The fact that much of the new infrastructure would not be revenue-generative is certainly part of the problem, though private sources could, in theory, fund public, non-revenue-generative infrastructure if, for example, invested as debt rather than equity. Yet two hurdles would still remain. First, as Clark et al. (2012) have noted, short-termism continues to dominate institutional investment, even among investors who can (as infrastructure requires) invest over inter-generational timespans. Second, private investment of all types remains, for the most part, profit-maximizing above other considerations, whereas investment in public infrastructures with a climate-change-mitigation-and-adaptation remit would, by its very nature, need to be constituted as low-risk and low-reward. This tension is already writ-large in the fact that private, ecologically-oriented infrastructure financing has yet to substantively materialize. As Simon Zadek (2013: np) notes, if a significant switch is not happening now - "mechanisms like the Green Climate Fund are struggling to get off the ground, and have yet to offer a vision for unlocking capital at scale," while major institutional investors continue to invest heavily in non-renewable fossil-fuel industries, remaining, collectively, "resolutely brown and dirty" - even with "the low cost of capital and the need to stimulate the global economy," it is arguably hard to see when it will.

4. The lack of substantive progress on the private financing front is probably also explicable in part by the fourth important obstacle requiring recognition: namely, active resistance (broadly-defined). Sayre (2010) regards one form thereof as particularly important: resistance from existing owners of current built environments to the devaluation that would necessarily accompany such capital's redesign, disuse and rebuilding. (Though, as Sayre also remarks, this capital will be devalued regardless, by climate change, if not by proactive social decision-making; but who says the owners of capital are rational?). Resistance also emanates from other influential sources. One is the oil and gas sector, with its entrenched power. Another, equally powerful, is the financial services sector. As Zadek (2013) explains, a prerequisite for major long-term private financing of built-environment reconstruction is meaningful reform in and reregulation of financial markets. But such reforms are not even close to happening, stymied as regulators are by "a fierce headwind of lobbying by financial firms" (ibid.) deeply invested in existing institutional configurations of risk and reward.

5. Last but not least, there is a pivotal geographical dimension to the financial challenge that lies ahead, and one closely bound up in complex ways with the distributional issues identified in the previous section. Put simply, there is marked geographical unevenness internationally both in the need to upgrade infrastructures and in the financial wherewithal to do so, rendering the geopolitical and geo-financial consensus and collectivity that is likely to be a necessary condition of success all the more difficult to achieve. Climate change, 
as Davis (2010, 37) writes, "will produce dramatically unequal impacts across regions," in the process "inflicting the greatest damage upon poor countries with the fewest resources for meaningful adaptation" and in a way that may "undermine ...pro-active solidarity." Put this concern alongside the more pointed fear that any climate change-related financial transfer from Global North to South "would be so firmly ring-fenced with conditionalities that it would auction away the sovereignty of African nations at the altar of 'Green Capitalism'"' (Tandon, 2011, 141), and the daunting difficulties of achieving a global capital-switch-cum-ecological-fix are clear to see.

\section{Grounds for cautious optimism}

With all of this said, it is not in our view sufficient - conceptually, empirically or politically - to leave things there: to bemoan, effectively, that capital is capital, and the future thus constrained by the inertia built into the current historical-geographic conjuncture. In amidst the undoubted grounds for skepticism, we see three main reasons for believing that finance capital can potentially facilitate the type of investment and rebuilding that is needed in the near future. These particular reasons can be added to the four very general ones described earlier in the article.

First, and in many ways least significantly, there are signs of potentially promising developments on the ground. In its recent report on cities and what it calls "infrastructure transitions" (UNEP, 2013), the United Nations' International Resource Panel included 30 case studies of "innovative approaches to sustainable infrastructure change across a broad range of urban contexts." Wholesale infrastructure renewal is not just a theory, in other words. One city often mentioned in this context, by way of example, is Chicago. The Chicago Infrastructure Trust (CIT) was established in 2012 to incentivize both debt- and equity-based private financing of a range of infrastructure projects. Chicago is also the leader of the international Sustainable Infrastructure Finance Network, which is a collective initiative, also launched in early 2012, by the so-called C40 group of cities.

While there does not appear to be anything particularly revolutionary about the financing models used in the aforementioned cases - Citibank and J P Morgan are both actively involved in the CIT - it is vital to appreciate, second, that different types of financial entity, with the potential to embrace different financing rationales, do exist, and are, in many cases, extremely well-capitalized. "Insurance companies, pension funds, sovereign wealth funds, endowments, foundations and family offices," note Clark et al. (2012, 104), "all have the ability to invest over inter-generational spans" and in "long-term, illiquid assets" - in, most notably, infrastructure assets. Such investors - which Oulton (2012), in the context of the funding of a low-carbon future, describes collectively as constituting "patient capital" - were reported as having had \$27 trillion in assets under management in 2011 (Clark et al. 2012, 104). 
SWFs appear to represent an especially encouraging investor type. For one thing, they occupy a "unique position" among investors insofar as they are "not constrained by liabilities" or "subject to increasing solvency requirements."

Furthermore, they typically have "greater discretion over tactical and strategic asset allocation," which explains why they are often described as "unconstrained investors" (Clark et al., 2013, 8-9). Of especial interest in relation to our own hypothesized capital switch and the alternative 'rewards' profile that financing thereof would be likely to exhibit - lower financial returns, but higher social-collectivist, non-monetary ones - is the 'moralist' SWF sub-category identified by Clark et al. Such funds include, inter alia, Australia's Future Fund and Norway's Government Pension FundGlobal. The former has an obligation to ensure that its investments are 'sustainable' in the sense of not harming the prospects of future generations; the latter represents "an expression of Norway's commitment to global justice" (ibid., 64, 68). Both would seem, at least from the outside, possible participants in a broadly-based ecological-fix financing initiative.

Third, finally, and perhaps most significantly of all, it is possible to identify precedents for socially-progressive, large-scale, infrastructure-oriented capital switches. In other words, it has - sort of - been done before, even if not on the same scale, and even if not with specifically environmental ends. One such precedent is discussed briefly now; we think others are equally pertinent, but space constraints preclude their elaboration. ${ }^{1}$ Our aim here is not to advance particular financing models to be replicated but to highlight an historical-geographical achievement - of political will as much as financial innovation - in the face of socio-economic need from which we can hopefully learn.

This particular example is somewhat ironic in the present context, given the environmental implications it ultimately had, but it is instructive nonetheless. It is a case very much of "market failure". When the mass-market provision of electricity was rolled out in the U.S. in the 1910s and 1920s, rural areas were largely neglected: the economics of building-out infrastructure to dwellings and farms not clustered together could not be made to work from the service providers' perspective, meaning that only those end-users able to advance the necessary financing themselves were initially connected up. The result was that by 1930 only approximately 10 percent of American farms had electricity, whilst rural electrification levels had reached in excess of 50 percent in countries including Czechoslovakia, France and Germany (Brown, 1980, 16-17).

\footnotetext{
${ }^{1}$ An important contemporary example of a substantial capital switch geared to financing infrastructure with a 'social' orientation (broadly defined), for instance, is that of European social housing, where in many countries innovative financing methods (e.g. the government acting as loan guarantor) have partially arrested the decline in social housing construction widely associated with the state's withdrawal from direct provision and with housing associations' growing reliance on otherwise expensive private financing.
} 
The Great Depression put ambitions for rural electrification on hold, but from 1934 renewed impetus was provided by two men in particular: President Franklin D. Roosevelt (who had been an outspoken advocate of rural electrification as Governor of New York state) and the engineer Morris Cooke, both of whom recognized the importance of electrification to rural economic and social life. The latter was the author of a hugely influential report which estimated the cost of comprehensive rural electrification and made proposals for how it could be financed - a report which Cooke later referred to as "the detonating force which started rural electrification" (ibid. 42).

In 1935, the Rural Electrification Administration (REA) was established. In time, the specific financing model used would come to be seen as critical to the program's success. The REA was, effectively, a funding agency. It did not procure and install infrastructure itself - instead, it provided loans to those who did, among whom were both private companies and, most significantly, cooperatives, which were formed (on a strictly not-for-profit basis) by rural residents to build distribution systems and provide their own electrical services. The REA's loans, towards which Congress in 1936 made available a maximum of $\$ 410 \mathrm{~m}$ over 10 years, featured three key (connected) components: federal subsidization; low (since subsidized) interest rates; and repayment schedules designed to match, in temporal terms, the timeframe (decades rather than years or months) over which the "returns" on investment would be realized by borrowers.

What was the outcome of the REA? As early as 1939, it had 417 cooperatives serving 268,000 rural households. After this initial burst of borrowing and investment, the pace of uptake slackened off during wartime before then picking up again from 1945. By 1953, "over 2.5 million farms were connected to REA and for all practical purposes, all American farmers had electricity, whether through REA or otherwise" (Schurr, 1990, 234); and Brown (1980, x), bringing the story up to the end of the 1970s, reported a default rate on REA loans since the agency's genesis of less than one percent.

\section{Conclusion: from bad debt to healthy credit, from present liquidity to future solidities}

It must be admitted that now is a particularly challenging time to be arguing for the positive potential of finance capital in making alternative socio-ecological futures. It goes against the grain of the bulk of writing on environmental questions in critical human and environmental geography. Moreover, debt has gotten a particularly bad name in the past five years in governmental and public spheres.

But finance capital, including credit creation, will be crucial to enabling us to adapt to a changing biophysical world and to mitigating some of that change. In particular, and in line with the focus of this article, built environments will need to be 
substantially reformatted and constituted afresh. Unless capitalism is replaced by another mode of production altogether (and, on some accounts, even if it is), this cannot be done without putting finance capital to work. Granted, such capital is in many of its forms centrally bound-up with capitalism's most exploitative and ecologically harmful circuits. We refuse to accept, however, that it must always be so or at least to the degree some critics suggest. We acknowledge that there are significant obstacles to an ecologically- and socially-progressive mobilization in the service of the "capital switch" envisioned here, yet we see signs of hope, not least in historical (and contemporary) examples of finance being put to extra-economic ends.

The often-sweeping condemnation of finance capital, and debt in particular, therefore needs revisiting. In recent years, few books have done more to give debt its bad name than David Graeber's (2011) eponymous history. As such, we will conclude by citing from a review of this weighty monograph which, while recognizing its many merits, calls for research and thinking about "healthy credit" alongside "bad debt." It is a sentiment, in the context of socio-ecological futures, with which we fully concur:

This hefty treatise on bad debt shows the need for further work on healthy credit. ... [We can denounce] capitalist "gambling". Yet all investment in future facilities involves an element of uncertainty and a claim on resources. Governments can conjure the needed money out of thin air if those investments turn out to meet a genuine and effective social need. Capitalists are often not very good at spotting and sponsoring necessary social innovations, especially those which require large-scale and complementary infrastructure. Public enterprise - carried out on a broad and varied canvas - is the vital missing ingredient in a world dogged by indebtedness, weak demand, climate catastrophe, poverty, crumbling infrastructure and counterproductive austerity (Blackburn, 2013, 150).

In this light, we might hope that leading governments will help finance capital realize its profound potential to remake the arteries through which capital flows and which are the lifeblood of the biological and social reproduction of most of contemporary humanity. Indeed, we need far-sighted state action because, in most parts of the world, we lack collective agents capable of forcing the hand of (often unwilling or ham-strung) governments. We might hope, too, that more social scientists, including many human geographers, can be generative of transformative ideas, evidence and proposals geared to creating a future we would like our successors to inherit. To help change the world for the better we may, as Karen O'Brien (2013) recently opined, have to change our own modus operandi. A critical geography of finance capital and infrastructural transformation clearly cannot and should not be a Polyanna, but neither can it afford to remain analytically skeptical or normatively gloomy about the prospects for a greener and more socially just capitalism. 


\section{References}

Blackburn, R. 2013. Finance for anarchists. New Left Review 79: 141-50.

Brown, D. 1980. Electricity for rural America: the fight for REA. Westport: Greenwood Press.

Clark, G., A. Monk, R. Orr, and W. Scott. 2012. The new era of infrastructure investing. Pensions 17(2): 103-111.

Clark, G., A. Dixon, and A. Monk. 2013. Sovereign Wealth Funds: Legitimacy, Governance, and Global Power. Princeton: Princeton University Press.

Davis, M. 2010. Who will build the ark? New Left Review 61: 29-46.

Defra. 2012. UK Climate Change Risk Assessment: Government Report. https:// www.gov.uk/government/ uploads/system/ uploads/attachment data/fi le/69487/pb13698-climate-risk-assessment.pdf.

Gibson-Graham, J-K. 2008. Diverse economies. Progress in Human Geography 32:613-632.

Graeber, D. 2011. Debt: the first 5,000 years. New York: Melville House.

Graham, S. and S. Marvin, 2001. Splintering urbanism: networked infrastructures, technological mobilities and the urban condition. London: Routledge.

Hallegatte, S., C. Green, R. Nicholls, and J . Corfee-Morlot. 2013. Future flood losses in major coastal cities. Nature Climate Change 3:802-806.

Harvey, D. 1978. The urban process under capitalism: a framework for analysis. International J ournal of Urban and Regional Research 2: 101-131.

Harvey, D. 1982. The Limits to Capital. Oxford: Blackwell.

O’Brien, K. 2013. Global environmental change III: closing the gap between knowledge and action. Progress in Human Geography 37 (4): 587-96.

O'Neill, P. 2013. The financialisation of infrastructure: the role of categorisation and property relations. Cambridge J ournal of Regions, Economy and Society doi: 10.1093/ cjres/rst017.

Oulton, W. 2012. Funding a low-carbon future. 14 May. http:// www.environmentalfinance.com/content/analysis/funding-a-low-carbon-future.html.

Pacala, S., and R. Socolow. 2004. Stabilization wedges: solving the climate problem for the next 50 years with current technologies. Science 305: 968-972. 
Sayre, N. 2010. Climate change, scale, and devaluation: the challenge of our built environment. Washington and Lee J ournal of Energy, Climate, and the Environment 1: 93-105.

Schurr, S. 1990. Electricity in the American economy: agent of technological progress. Westport: Greenwood Press.

Stern, N. 2007. The Economics of Climate Change. Cambridge: Cambridge University Press.

Stone, B. 2012. The City and the Coming Climate: Climate Change in the Places We Live. Cambridge: Cambridge University Press.

Swyngedouw, E. 2010. Apocalypse forever? Post-political populism and the spectre of climate change. Theory, Culture \& Society 27: 213-232.

Tandon, Y. 2011. Kleptocratic capitalism, climate finance, and the green economy in Africa. Capitalism Nature Socialism 22(4): 136-144.

UNEP. 2013. City-level decoupling: urban resource flows and the governance of infrastructure transitions. http:// www.unep.org/resourcepanel/portals/24102/pdfs/CitiesFull_Report.pdf.

Zadek, S. 2013. Greening financial reform. 26 J uly. http:// www.projectsyndicate.org/ commentary/ integrating-the green-growth-imperative-andfinancial-market-reform-by-simon-zadek. 